\title{
Feeding ecology of the beach silverside Atherinella blackburni (Atherinopsidae) in a tropical sandy beach, Southeastern Brazil
}

\author{
Júlio Guazzelli Gonzalez ${ }^{1 *}$,Teodoro Vaske Júnior ${ }^{l}$ \\ ${ }^{1}$ Universidade Estadual Paulista "Júlio de Mesquita Filho" - Campus do Litoral Paulista - Instituto de Biociências \\ (Praça Infante Dom Henrique s/n, Parque Bitaru, 11380-972, São Vicente, SP, Brazil) \\ *Corresponding author: julio.gonzalez@ufrpe.br
}

\begin{abstract}
The feeding ecology of the beach silverside (Atherinella blackburni) in the surf zone of a tropical sand beach, located in the southeastern Brazil, was accessed through the gut content analysis of 198 fish. Factors such as fish's size, season and day period were analysed to understand how these variables affect the diet composition of the species. Results show that A. blackburni is a coastal neritic fish with a broad feeding niche. Most recurrent prey were zooplanktonic crustaceans, insects and benthic molluscs, in which Copepoda crustaceans were the dominant dietary item in occurrence and abundance. $A$. blackburni appears to have a slight ontogenetic shift in its diet, changing from benthic molluscs to crustaceans and insects along its life cycle. The diel activity also reveals to be an important factor to the A. blackburni feeding ecology. The predominant occurrence of small fish during the morning, along with the main preys for this size class, suggests that small individuals use shallower waters as feeding grounds during the morning and, during the night, they move to deeper waters for protection against predators.
\end{abstract}

Descriptors: Diel activity, Diet, Ontogenetic shift, Resources partitioning, Surf zone, Zooplanktivorous.

\section{RESUMO}

A ecologia alimentar do peixe-rei (Atherinella blackburni) na zona de arrebentação de uma praia arenosa tropical, localizada no sudeste do Brasil, foi acessada a partir da análise do conteúdo alimentar de 198 peixes. Fatores como o tamanho, a estação do ano e o período do dia foram analisados para compreender como estes influenciam a dieta da espécie. Os resultados mostram que A. blackburni é um peixe nerítico costeiro com amplo nicho alimentar. As presas mais recorrentes foram os crustáceos zooplanctônicos, insetos e moluscos bentônicos, sendo os crustáceos da subclasse Copepoda o item dominante na dieta em ocorrência e abundância. A. blackburni aparenta possuir uma leve mudança ontogênica em sua dieta, variando de moluscos bentônicos para crustáceos e em seguida para insetos ao longo do seu ciclo de vida. A atividade diária também demonstrou ser um fator importante para a ecologia alimentar de A. blackburni. O predomínio de peixes pequenos durante o período da manhã, juntamente com as principais presas para esta classe de tamanho, sugere que indivíduos pequenos utilizem as áreas mais rasas para alimentação durante o período da manhã e, durante a noite, movem-se para águas mais profundas em busca de proteção contra predadores.

Descritores: Atividade diária, Dieta, Mudança ontogênica, Partição de recursos, Zona de arrebentação, Zooplanctívoro. 


\section{INTRODUCTION}

The surf zone is a dynamic environment influenced mainly by the waves action. The high rates of primary production (ANDRADES et al., 2014; ODEBRECHT et al., 2014) and turbidity (ALSINA; CÁCERES, 2011) associated to these coastal environments makes them essential habitats for several species of fish, providing food and protection from predators (LASIAK; MCLACHLAN, 1987; BLABER; BLABER, 1980; ESPOSITO et al., 2013; PATTRICK; STRYDOM, 2014; FAVERO; DIAS, 2015). Such shallow and turbulent environments favour, in most cases, the presence of fish in early stages of life (LAYMAN, 2000). However, few species, such as the beach silverside Atherinella blackburni (SCHULTZ, 1949), have adapted to such conditions and are able to inhabit these places during different life stages.

A. blackburni is a small fish of the Atherinopsidae family that inhabits the surf zone of beach environments and measures up to $130 \mathrm{~mm}$ and $12.67 \mathrm{~g}$ (MATTOX et al., 2008). Unlike other Atherinopsids commonly found in Brazilian waters (e.g. Atherinella brasiliensis and Odontesthes bonariensis), A. blackburni prefers high water temperature and salinity (MATTOX et al., 2008), with a sparse distribution limited to the West Atlantic and occurrence throughout Central and South America. Specimens were found in Honduras (MATAMOROS et al., 2009), Costa Rica (GILBERT; CALDWELL, 1967), Venezuela (SCHULTZ, 1949; GASPAR; ÁVILA, 2009) and Brazil (GILBERT; CALDWELL, 1967; LOPES; OLIVEIRA-SILVA, 2001; MAZZEI et al., 2011; OLIVEIRA; PESSANHA, 2014; GARCIA-JÚNIOR et al., 2015). The current austral limit of the species is at the northern coast of São Paulo state in Brazil (GONDOLO et al., 2011).

Atherinopsid fishes are widely studied, especially the silverside Atherinella brasiliensis, which is the only congener of $A$. blackburni frequently found in brazilian estuaries (FIGUEIREDO; MENEZES, 1978). Several studies have addressed the aspects of ecology, feeding strategy and life cycle of $A$. brasiliensis (PESSANHA; ARAÚJO, 2001; FAVARO et al., 2003, 2007; NEVES et al., 2006; CONTENTE et al., 2010). However, there are few studies on the biology of A. blackburni (e.g. MATTOX et al., 2008) due to their discontinuous distribution and low occurrence, and none assessing the feeding ecology of this species. Moreover, since the life cycle of A. blackburni is restricted to shallow areas of beach environments (LOPES; OLIVEIRA-SILVA, 2001; MATTOX et al., 2008), this species might be an important model for elucidating how the surf zone influences the fish species at different life stages.

This study describes the diet and feeding strategy of $A$. blackburni in a tropical sandy beach. Further, it highlights the importance of beach environments for fish in the early life stages and evaluate how the size of individuals, seasonality and time of the day influence the feeding pattern of the species.

\section{MATERIAL AND METHODS}

\section{STUDY AREA AND SAMPLING PROCEDURES}

Located in the central coast of São Paulo, southeastern Brazil, the city of Praia Grande has a $24 \mathrm{~km}$ long, low slope sandy beach in its coastal portion (Figure 1). With little influence of the adjacent estuaries, the beach environment of Praia Grande has constant values of salinity $(33.25 \pm 0.4)$ and temperature $\left(23.37 \pm 0.35{ }^{\circ} \mathrm{C}\right)$ (personal data). Throughout the year, the seasonal differences in the region of Praia Grande are slightly pronounced, with an average rainfall of $226 \mathrm{~mm}$ and rainfall peaks during the summer $(364.75 \mathrm{~mm})$ and dry periods in the winter (98.63 mm) (DAEE, 2015). Else, in high rainfall seasons, several effluents that connect the urban fringe to the sea are formed on the stretch of sand.

The study site comprised the surf zone of the beach in Praia Grande (2401'59'S - 46²5'34'W). Bimonthly sampling campaigns were conducted between October 2012 and April 2015, with daytime (8 to $11 \mathrm{~h}$ ) and evening samples (19 to $21 \mathrm{~h}$ ), except for February/2013 and February/2015 when samplings could not be carried out. Due to the scarcity of specimens in some samples, the samplings were grouped into dry and rainy seasons to further analyse, which corresponded to the periods of autumn and winter (April to August, 7 campaigns) and spring and summer (October to February, 7 campaigns), respectively (NUNES; MODESTO, 1992).

The fish were captured using a beach seine net with a mesh size of $4.0 \mathrm{~mm}$, cloth of $10 \times 2$ meters and a central triangular bag of 1.80 meters high and 1.30 meters deep. In each sampling, three trawls were carried out parallel to the coastline, each with approximately 50 meters of transect at an average depth of one meter. The collected fish were properly conditioned in ice for posterior laboratory analysis. The identification of species was based on the diagnosis proposed by MATTOX et al. (2008), which lists 


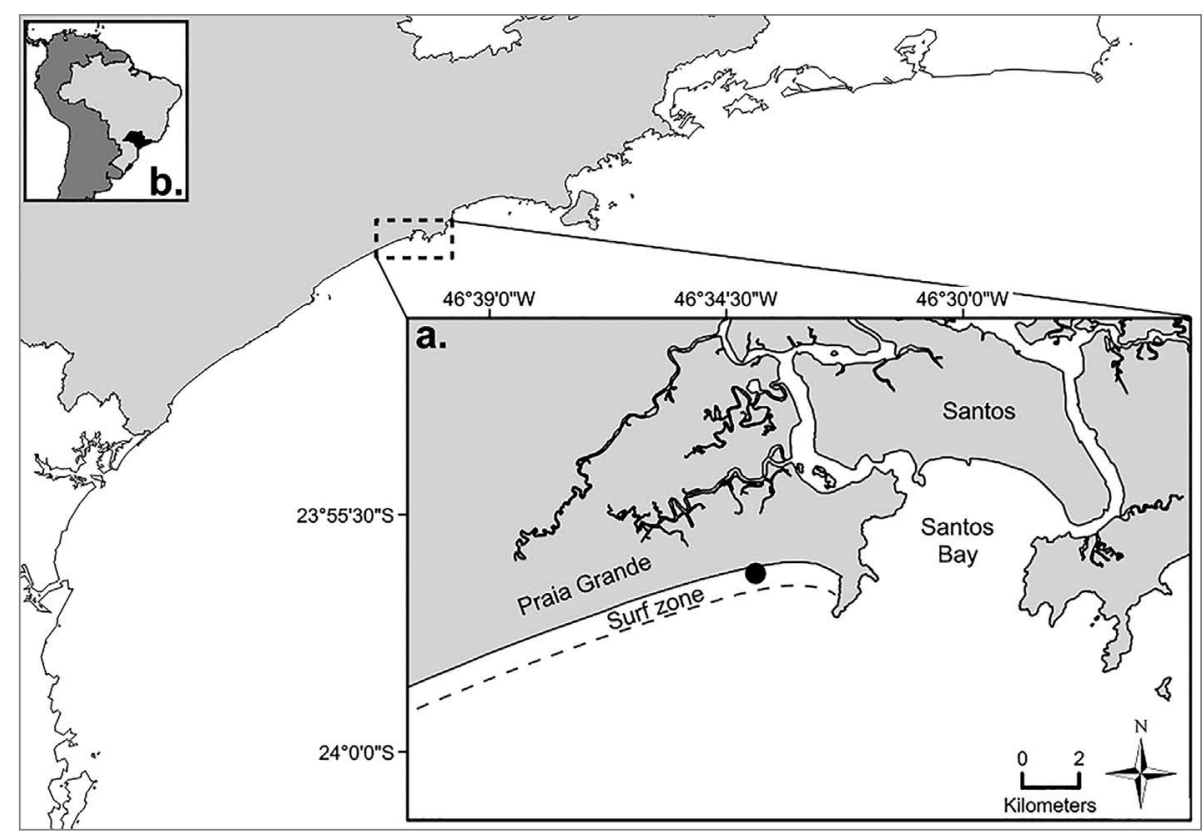

Figure 1. Surf zone of the sandy beach in Praia Grande (a), located in São Paulo state, southeastern Brazil (b). Sampling area is represent by the black dot.

characteristics to differentiate $A$. blackburni from other Atherinopsids regularly found in Brazilian waters.

In the laboratory the specimens had their total length (TL - $\mathrm{mm}$ ) measured and the digestive tracts extracted. As A. blackburni does not have a discrete stomach, the entire contents of the digestive tract were analysed, identified and quantified under stereomicroscope (35x). Due to the size and degree of digestion, analysed items were identified into major categories (e.g. Gastropoda) and, whether possible, to lowest taxonomic levels.

\section{DATA ANALYSIS}

The total length (TL) of the individuals was submitted to a Mann Whitney's test to verify if the size distribution differs between periods (day - night) and seasons (dry - rainy).

To evaluate whether the sample size was sufficient to describe the diet of A. blackburni, a cumulative curve of types of prey was performed based on the randomization of 999 digestive tracts with food (FERRY; CAILLIET, 1996). A. blackburni diet and importance of each prey item was described by the frequency of occurrence $(F i)$ and numerical frequency $(\mathrm{Ni})$ of dietary items (BAKER et al., 2014). $F i$ is the number of individuals containing the item $i$ divided by the total number of analysed individuals. $N i$ is the absolute number of item $i$ divided by the total number of observed items. When considering the uncertainty associated with the indices used, the confidence interval (95\%) for each item was obtained from a bootstrap method with 5000 re-sampling trials (TIRASIN; JØRGENSEN, 1999).

The feeding strategy of the species has been accessed from the method proposed by AMUNDSEN et al. (1996). In this method, the prey-specific abundance $(P i)$ and the frequency of occurrence $(F i)$ of each item were arranged in a two-dimensional graph. The $P i$ of each item is the number of items $i$ divided by the total number of items present in individuals where the item $i$ was observed (AMUNDSEN et al., 1996). The distribution of points on the graph in this method indicates the importance and the occurrence of each item for the diet of the species.

A nonparametric multivariate analysis of variance (PERMANOVA) with 999 permutations was performed to check whether the observed diet data are influenced by the size, period of the day and season. PERMANOVA procedure performs a sequential test of variables based on distance matrices (ANDERSON, 2001), which allows the hypothesis testing between seasons, period of the day, size and the interaction between these factors. Due to the high variability in the diet of individuals with different sizes, the variable size was considered as a categorical variable with four levels based on the size at first maturity of another Atherinopsid (i.e. Atherinella brasiliensis - approximately $70 \mathrm{~mm}$ of total length (FAVARO et al., 2003)): i. juveniles, fish smaller than 
$30 \mathrm{~mm}$; ii. pre-maturation juveniles, fish between 31 and $60 \mathrm{~mm}$; iii. post-maturation adults, fish between 61 and 90 $\mathrm{mm}$; iv. adults, fish larger than $91 \mathrm{~mm}$. Season and period of the day were also classified as categorical variables, with two levels each (season: dry/rainy; period: day/night). All variables were set as fixed factors and the design was assumed to be balanced. The test was based on a BrayCurtis similarity matrix using the dietary matrix $\log (n+1)$ transformed, in which each individual was considered a sample unit. Occasional food items (occurrence lower than $10 \%$ ) were excluded from analysis.

In order to elucidate the effect of size, season and day period in the diet composition of the individuals, a correspondence analysis (CA) was performed based on the absolute values of the diet matrix. This ordination used food items as centroids to dispose the observed individuals. Subsequently, the variables were correlated to the resulting ordering of CA trough Pearson's statistic. In this case, the size was considered as a continuous variable, whereas season and time of the day represented categorical variables as described above. All statistical procedures were performed using the software R 3.2.3 ( $\mathrm{R}$ CORE TEAM, 2015) with the packages boot (CANTY; RIPLEY, 2016) and vegan (OKSANEN et al., 2016) for bootstrapping and PERMANOVA procedures respectively.

\section{RESULTS}

A total of 198 specimens of A. blackburni were collected with total lengths between 15 and $120 \mathrm{~mm}$. Size distributions were significantly different between seasons (Mann Whitney: $\mathrm{W}=2346, p<0.01$ ) and sampling periods (Mann Whitney: $\mathrm{W}=3560, p<0.01$ ) (Figure 2). Smaller fish were more abundant in the dry season than in rainy season (Figure 2a). A similar pattern was observed for fish occurring during the morning compared to night (Figure $2 b)$, but with less intensity.

Among all specimens collected, 185 (93.43\%) had at least one identifiable item in their digestive tract. The items found were identified in 18 different categories, most notably the copepods, insects and mysids, which had the highest values of occurrence frequency (Table 1). Bivalves, gastropods, insect larvae, unidentified insects and unidentified crustaceans were also recurring items in the digestive tracts analysed ( $F i \geq 10 \%$ and $N i \geq 2 \%$ ). Other found items reflected the occasional predation by some individuals $(F i<10 \%$ and $N i<2 \%)$ and were not representative for the diet of $A$. blackburni. The number of guts analysed in this study appears to be sufficient to describe their diet, since the cumulative curve of types of food items seems to stabilize (Figure 3).

Based on the method proposed by AMUNDSEN et al. (1996), the feeding strategy of A. blackburni can be classified as generalist with wide food spectra. Most food items are located in the lower left region of the graph, suggesting little specialization and occasional occurrence of these prey (Figure 4). Among the food items, Copepod crustaceans were the dominant and the most important item on the diet. Insect larvae appears to be the preferred item only for a few individuals.

PERMANOVA test showed that all variables influence the diet composition of A. blackburni (Table 2), with day period having greater influence. However, the high intraspecific variability in the diet composition obscures the power of the variables season and time of the day in explaining the phenomenon. Fish size is the variable that best explains the variation in the diet composition, and its effect can easily be observed when compared to the relative abundance of the prey between fish of different sizes (Figure 5).

Correspondence analysis reveals how individuals are arranged according to the main food items (Figure 6). The first CA axis (CA1) was responsible for segregating individuals with different abundances between crustaceans/molluscs and insects. The second axis of the CA (CA2) showed a gradient between the food items, ranging from molluscs to crustaceans and then to insects. The total variance explained by the first two axes of the CA was $41.42 \%$

Among the variables correlated to the first two CA axes, size $\left(r^{2}=0.24\right)$ and time of day $\left(r^{2}=0.17\right)$ showed higher correlation to the resulting distribution, whereas season is not correlated with these axes $\left(r^{2}=0.01\right)$. The size of fish is related mostly with the CA2 axis, in which individuals with smaller sizes (i.e. approximately $20 \mathrm{~mm}$ ) are associated with the bivalves and gastropods and, the higher their size, the more this association changes to mysids and unidentified crustaceans, then insects and copepods. On the other hand, the time of the day has a higher relation with the CA1 axis, with the diurnal period associated with small crustaceans, especially copepods, and nocturnal period with insects and insect larvae. 


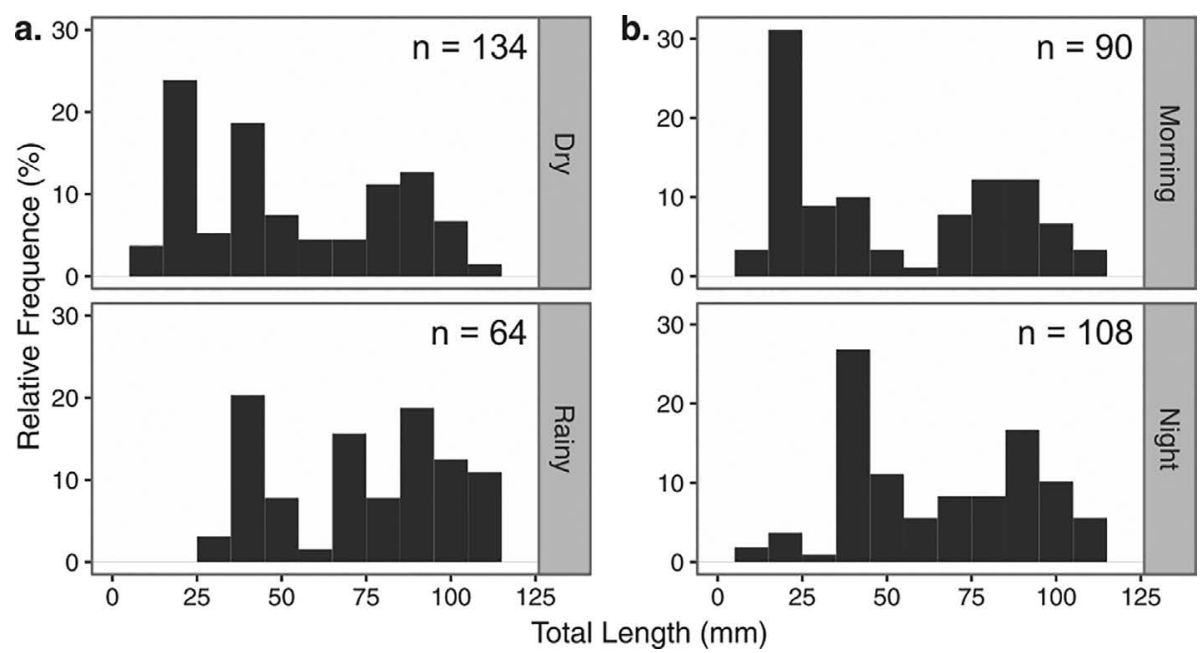

Figure 2. Relative frequency of individual's length (TL - mm) of Atherinella blackburni during seasons (a) and daytime (b) in a tropical sandy beach, southeastern Brazil. Fish were grouped in $10 \mathrm{~mm}$ intervals. The number of individuals (n) collected in each season and day period is given in the upper right corner of each plot.

Table 1. Occurrence $\left(F_{i}\right)$ and numeric $\left(N_{i}\right)$ frequencies of dietary items and major taxonomic categories of Atherinella blackburni diet in a tropical sandy beach, southeastern Brazil. The confidence interval (IC - 95\%) accessed by bootstrap method is given for each item.

\begin{tabular}{|c|c|c|c|c|c|}
\hline \multicolumn{2}{|l|}{ Dietary items } & $F_{i}(\%)$ & $\mathrm{IC}_{95 \%}$ & $N_{i}(\%)$ & $\mathrm{IC}_{95 \%}$ \\
\hline \multicolumn{2}{|l|}{ MOLLUSCA } & 20.54 & $(15.14-27.03)$ & 4.54 & $(3.0-6.23)$ \\
\hline \multicolumn{2}{|l|}{ Bivalvia } & 18.92 & $(13.51-24.86)$ & 2.42 & $(1.47-3.61)$ \\
\hline \multicolumn{2}{|l|}{ Gastropoda } & 12.43 & $(8.11-17.3)$ & 2.0 & $(1.1-3.16)$ \\
\hline \multicolumn{2}{|l|}{ Scaphopoda } & 1.08 & $(0.0-2.7)$ & 0.13 & $(0.0-0.33)$ \\
\hline \multicolumn{6}{|l|}{ ANNELIDA } \\
\hline \multicolumn{2}{|l|}{ Polychaeta } & 1.08 & $(0.0-2.7)$ & 0.1 & $(0.0-0.29)$ \\
\hline \multicolumn{6}{|c|}{ ARTROPODA } \\
\hline \multirow[t]{4}{*}{ Hexapoda } & & 50.81 & $(43.78-57.84)$ & 30.84 & $(22.63-39.88)$ \\
\hline & Insecta & 36.76 & $(29.73-43.78)$ & 8.34 & $(5.61-11.64)$ \\
\hline & Insecta Larvae & 19.46 & $(14.05-25.41)$ & 15.46 & $(9.36-22.69)$ \\
\hline & Unidentif. Insecta $\dagger$ & 21.08 & $(15.41-27.03)$ & 7.05 & $(4.05-10.99)$ \\
\hline \multirow[t]{9}{*}{ Crustacea } & & 74.05 & $(67.57-80.0)$ & 63.98 & $(46.83-83.53)$ \\
\hline & Amphipoda & 0.54 & $(0.0-1.62)$ & 0.03 & $(0.0-0.08)$ \\
\hline & Cirripédia (Ciprys) & 0.54 & $(0.0-1.62)$ & 0.1 & $(0.0-0.32)$ \\
\hline & Cladocera & 9.73 & $(5.41-14.05)$ & 1.44 & $(0.72-2.2)$ \\
\hline & Copepoda & 47.03 & $(40.0-54.05)$ & 39.5 & $(28.38-49.59)$ \\
\hline & Decapoda & 2.16 & $(0.54-4.32)$ & 0.1 & $(0.02-0.21)$ \\
\hline & Mysidacea & 32.43 & $(25.95-39.46)$ & 10.53 & $(6.5-15.57)$ \\
\hline & Ostracoda & 2.16 & $(0.54-4.32)$ & 0.4 & $(0.02-1.01)$ \\
\hline & $\begin{array}{c}\text { Unidentif. Crusta- } \\
\text { cean } \dagger\end{array}$ & 30.27 & $(23.78-37.3)$ & 11.87 & $(7.46-17.06)$ \\
\hline \multicolumn{6}{|l|}{ Chelicerata } \\
\hline & Arachnida & 2.7 & $(0.54-5.41)$ & 0.15 & $(0.02-0.32)$ \\
\hline \multicolumn{6}{|l|}{ TELEOSTEI } \\
\hline & Unidentif. Fish $\dagger$ & 2.7 & $(0.54-5.41)$ & 0.13 & $(0.02-0.25)$ \\
\hline \multicolumn{2}{|c|}{ PLANT DETRITUS } & 4.32 & $(1.62-7.57)$ & 0.25 & $(0.09-0.45)$ \\
\hline
\end{tabular}

${ }^{\dagger}$ Items found only in part and/or under digestion, unable to identify. 


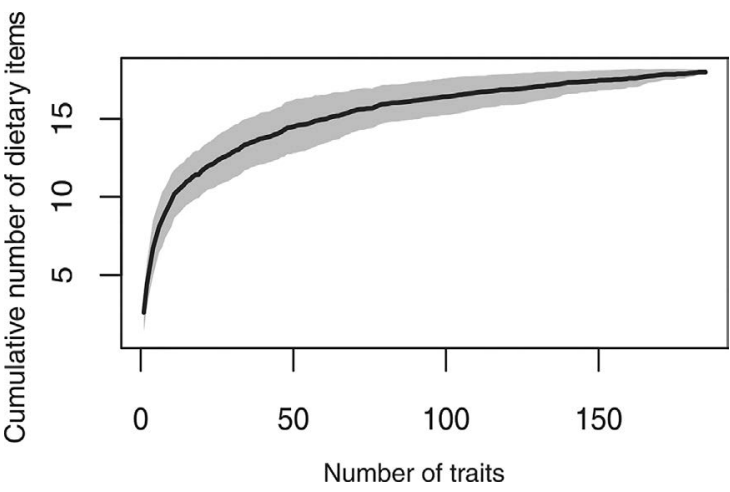

Figure 3. Cumulative curve of prey type based in 999 random orders of 185 non-empty traits of Atherinella blackburni in a tropical sandy beach, southeastern Brazil. The grey area represents the standard deviation of the estimated curve.

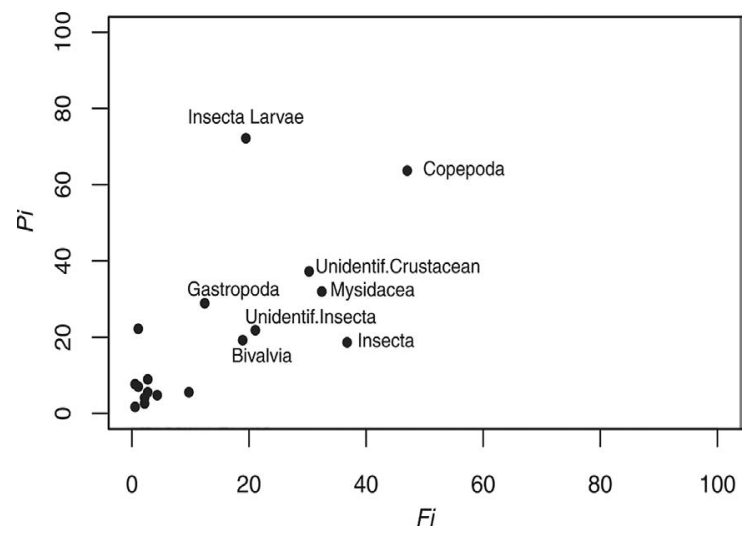

Figure 4. Feeding strategy of Atherinella blackburni in a tropical sandy beach, southeastern Brazil, according to AMUNDSEN et al. (1996). Only the name of main prey $(F i>10 \%)$ are given. $P i=$ preyspecific abundance. $F i=$ frequency of occurrence.

\section{DISCUSSION}

This study shows that A. blackburni has a feeding strategy with a broad niche and feeding consistency, with most of the individuals containing food in their digestive tract, regardless of the time of day or season. Their diet is based mainly on zooplanktonic crustaceans, which were the most common (74.05\%) and abundant (63.98\%) items. Among these crustaceans, copepods were the dominant item to most individuals at different stages of life.

These results corroborate the expected feeding strategy for fishes from the Atherinopsidae family, which generally feed on any available prey (RODRIGUES; BEMVENUTI, 2001; PIEDRAS; POUEY, 2005; HORN et al., 2006; CONTENTE et al., 2010). Moreover, the prevalence of crustaceans in the diet is common to species that actively explore the water column in search of food, such as A. blackburni (LASIAK; MCLACHLAN, 1987; PALMEIRA; MONTEIRO-NETO, 2010; NIANG et al., 2010; CONTENTE et al., 2010). Insects are the only item that probably is influenced by local conditions. Their constant occurrence in stomach contents could be related to the large green area in front of the sampling site that carries insects through the air or through rainwater to the sea. Predation on insects could also be facilitated by strong pigmentation and subsequent visualisation on the water by the larger fish. Although insects occur in some studies (LASIAK, 1986; NIANG et al., 2010; PALMEIRA; MONTEIRO-NETO, 2010), the observed proportions in this study were much higher.

Among the variables analysed, the size of specimens best explained the variation in the diet composition of $A$. blackburni. Although individuals feed on the same types of prey, the proportion of these preys varied with size (see Figure 5), showing a slight ontogenetic change in their diet. Throughout their life cycle, the species feed on benthic molluscs in the early life stages and then actively prey on crustaceans and insects present in the water column after reaches larger sizes $(>30 \mathrm{~mm})$. Two possible hypotheses may explain this phenomenon. First, dietary ontogenetic changes are expected in fishes, since individuals tend to eat larger and more energetic preys as they grow in size and increase their mouth's gap (CONTENTE et al., 2009; WARD-CAMPBELL et al., 2005). However, the presence of insect larvae and zooplanktonic crustaceans in the digestive tract of individuals smaller than $25 \mathrm{~mm}$ demonstrates the ability to feed on large preys even in early stages of life.

Second, although A. blackburni has a generalist strategy, individuals smaller than $30 \mathrm{~mm}$ seems to prefer smaller and possibly less energetic prey (i.e. gastropods and bivalves). In contrast, this behaviour tends to reduce competition with larger fish for food (SCHOENER, 1982). A similar pattern was observed by PEREIRA et al. (2015), where the habitat use and resources partitioning by four species of reef fish (Haemulon spp.) resulted from ontogenetic changes in their diet. Both hypotheses show the importance of the surf zone environment for juvenile fish species, in which, due to wave action, benthic organisms such as bivalves and gastropods are lifted into the water column and become easy prey for small fish.

Seasonality showed less yet significant influence in diet composition. Considering that the availability of food in the surf zone varies according to physicochemical conditions and season (GONÇALVES; MARQUES, 
Table 2. PERMANOVA results of how fishes size, season and day period affect the diet composition of Atherinella blackburni in a tropical sandy beach, southeastern Brazil.

\begin{tabular}{lccccc}
\hline Explanatory variable & d.f. & MS & pseudo- $F$ & $r^{2}$ & $p$-value \\
\hline Size & 3 & 3.050 & 12.245 & 0.14 & 0.001 \\
Day Period & 1 & 3.601 & 14.457 & 0.05 & 0.001 \\
Season & 1 & 2.926 & 11.746 & 0.04 & 0.001 \\
Size x Day Period & 3 & 0.608 & 2.442 & 0.02 & 0.002 \\
Size x Season & 3 & 0.444 & 1.784 & 0.02 & 0.016 \\
Day Period x Season & 1 & 1.683 & 6.759 & 0.02 & 0.001 \\
Residual & 170 & 0.249 & & &
\end{tabular}

Diet matrix with 183 traits x 8 dietary items. d.f. degrees of freedom. MS. Mean squares.

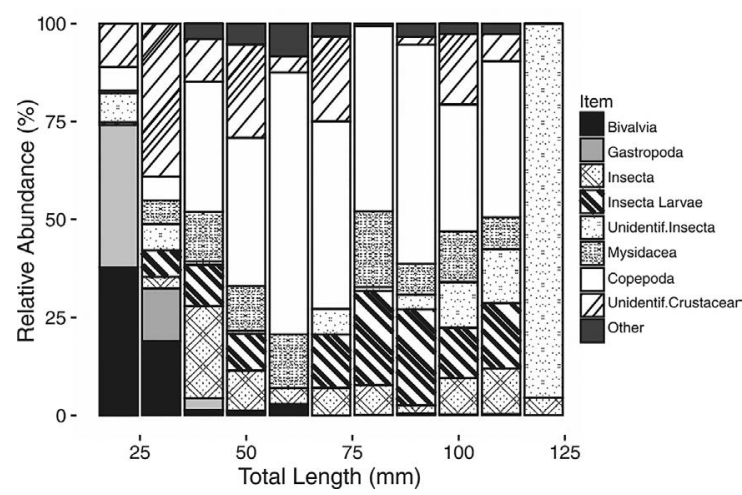

Figure 5. Relative abundance of main dietary items $(F i>10 \%)$ observed in different sizes of Atherinella blackburni in a tropical sandy beach, southeastern Brazil. Individuals were grouped in 10 $\mathrm{mm}$ intervals. Unidentif. Items, items found only in part and/or under digestion, unable to identify.

\section{1; PIEDRAS; ODEBRECHT, 2012; ODEBRECHT}

et al., 2014), our results confirm that $A$. blackburni has a generalist strategy and feeds on any available organisms. Furthermore, seasonality has been an important factor for the population structure throughout the year, with smaller fish captured during the dry season, particularly during the autumn and winter. This result differs in part from a previous study by MATTOX et al. (2008), who suggest that the recruitment of $A$. blackburni occurs during summer and autumn, when there is a higher incidence of small individuals. Although not conclusive since there is a low number of studies, the recruitment period of A. blackburni appears to occur during autumn. The effect of seasonality on existing fish stocks in the surf zone is a subject already addressed in different researches (FÉLIX et al., 2007; GOMES et al., 2003; SANTANA et al., 2013). However, these studies analysed only transient species of fish and related this effect to reproduction peaks of the species, without assessing the seasonal effect in populations that exhibit a lifecycle restricted to surf zone.

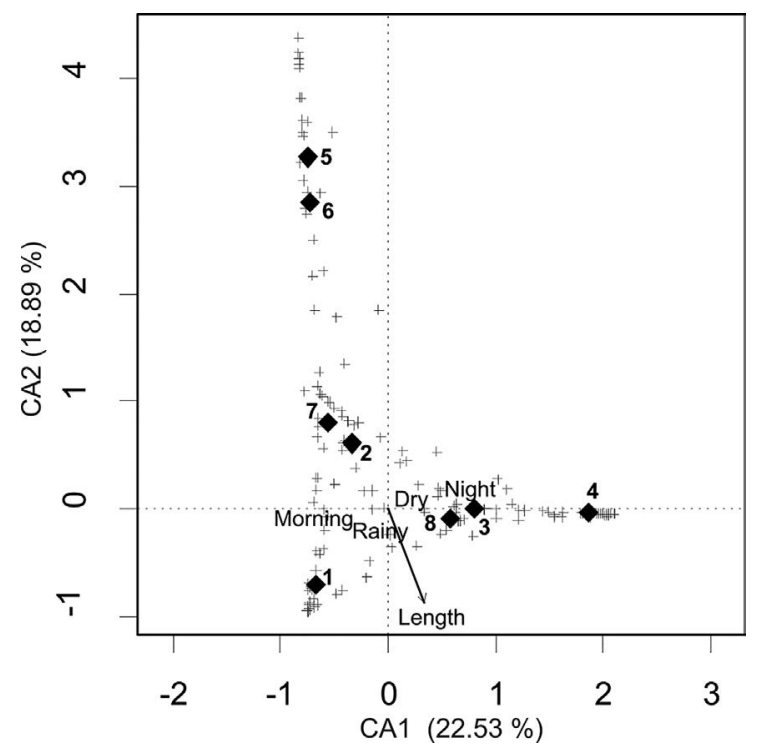

Figure 6. Correspondence analysis of Atherinella blackburni specimens $(+)$ based in the abundance of main preys $(\bullet)$ and its correlation with fishes size (black arrow), season and day period. The explained variation by each axis is given along the respective axis name. Dietary items: 1 . Copepoda; 2 . Mysidacea; 3 . Insecta; 4 . Insecta Larvae; 5. Gastropoda; 6. Bivalvia; 7. Unidentified Crustaceans; 8. Unidentified Insecta; 9. Other.

The diel activity is a limiting factor for many species of fish, especially marine species. Diel activity is related to seasonal and ontogenetic changes during their life cycles, which is important for an individual feeding and survival (REEBS, 2002). In this study, the time of day had great influence on the diet composition of $A$. blackburni. Zooplanktonic crustaceans (e.g. mysids) have daily horizontal migration, from higher densities in shallow water in the morning to deeper waters at night (NONOMURA et al., 2007), which is consistent with the observed relationship between crustaceans items found and daytime. Moreover, it is possible that the difference observed in the diet composition is closely related to the 
population structure of $A$. blackburni in each period of the day. The predominance of small fish in the morning along with the predominant items in their diet might suggest that individuals of up to $30 \mathrm{~mm}$ feed in the surf zone during daytime, moving to deeper water at night in search for protection against predators (REEBS, 2002; GAELZER; ZALMON, 2008).

Overall, atherinopsid fishes are opportunistic foragers that inhabit shallow waters and actively feeds on a board range of available preys (RODRIGUES; BEMVENUTI, 2001; PIEDRAS; POUEY, 2005; CONTENTE et al., 2010; ALVES et al., 2016). Although our findings corroborates the feeding strategy expected for silversides, a few differences in diet composition between A. blackburni and its most recurrent congener, $A$. brasiliensis, can be highlighted. $A$. brasiliensis is an estuarine resident specie that feeds upon a wide array of organisms, from fishes to zooplanktonic crustaceans and plant detritus (CHAVES; VENDEL, 2008; CONTENTE et al., 2010; ALVES et al., 2016). Notably, plant detritus and diatoms shows to be an important dietary item for A. brasiliensis (CONTENTE et al., 2010), and suggests that this specie feeds at a lower trophic level than A. blackburni. However, such differences between the two silversides are more likely to be associated with the food availability on the respective habitat of each species (e.g. ALVES et al. (2016)). Further, the stronger ontogenetic shift observed in A. blackburni diet, in contrast to the lack of size-related shift reported for $A$. brasiliensis (CONTENTE et al., 2010; ALVES et al., 2016), might reflect the higher growth rate observed for this species (MAZZEI et al., 2011), and the increase need for more nutritive preys at such stressful environment.

Despite the low accuracy of the items identified in this study due to the high degree of prey digestion, the number of items was sufficient to evidence ontogenetic, seasonal and daily differences in the diet composition of A. blackburni in the surf zone of a tropical sandy beach. The results presented here illustrate the importance of the surf zone in the life cycle of coastal fish species, in view of the recurring impacts to the beach environment with the expansion of urban areas in the cities (DEFEO et al., 2009; HARRIS et al., 2014; NEL et al., 2014).

Future studies on the ecology and reproductive biology of A. blackburni will help contemplate the gaps found in this study, as well as provide crucial information to elucidate the reasons for the discontinuous distribution of the species along the east coast of Central and South America (MATTOX et al., 2008).

\section{REFERENCES}

ALVES, V. E. N.; PATRÍCIO, J.; DOLBETH, M.; PESSANHA, A.; PALMA, A. R. T.; DANTAS, E. W.; VENDEL, A. L. Do different degrees of human activity affect the diet of Brazilian silverside Atherinella brasiliensis? J. Fish Biol., v. 89, n. 2, p. 1239-1257, 2016

ALSINA, J. M.; CÁCERES, I. Sediment suspension events in the inner surf and swash zone. Measurements in large-scale and high-energy wave conditions. Coast. Eng., v. 58, n. 8, p. 657670, 2011.

AMUNDSEN, P. A.; GABLER, H. M.; STALDVIK, F. J. A new approach to graphical analysis of feeding strategy from stomach contents data-modification of the Costello (1990) method. J. Fish Biol., v. 48, n. 4, p. 607-614, 1996.

ANDERSON, M. J. Permutation tests for univariate or multivariate analysis of variance and regression. Can. J. Fish. Aquat. Sci., v. 58, n. 3, p. 626-639, 2001.

ANDRADES, R.; GOMES, M. P.; PEREIRA-FILHO, G. H.; SOUZA-FILHO, J. F.; ALBUQUERQUE, C. Q.; MARTINS, A. S. The influence of allochthonous macroalgae on the fish communities of tropical sandy beaches. Estuar. Coast. Shelf Sci., v. 144, p. 75-81, 2014.

BAKER, R.; BUCKLAND, A.; SHEAVES, M. Fish gut content analysis: robust measures of diet composition. Fish Fish., v. 15, n. 1, p. 170-177, 2014

BLABER, S. J. M.; BLABER, T. G. Factors affecting the distribution of juvenile estuarine and inshore fish. J. Fish Biol., v. 17, n. 2, p. 143-162, 1980.

CANTY, J.; RIPLAY, B. boot: Bootstrap R (S-Plus) Functions. R package version 1.3-18, 2016. Available: <https://cran.r-project.org/web/packages/boot/boot.pdf $>$. Accessed: 2017 May 27

CHAVES, P. T.; VENDEL, A. L. Análise comparativa da alimentação de peixes (Teleostei) entre ambientes de marisma e manguezal num estuário do sul do Brasil (Baía de Guaratuba, Paraná). Rev. Bras. Zool., v. 25, n. 1, p. 10-15, 2008.

CONTENTE, R. F.; STEFANONI, M. F.; GADIG, O. B. F. Sizerelated shifts in dietary composition of Centropomus parallelus (Perciformes: Centropomidae) in an estuarine ecosystem of the southeastern coast of Brazil. J. Appl. Ichthyol., v. 25, n. 3, p. 335-342, 2009.

CONTENTE, R. F.; STEFANONI, M. F.; SPACH, H. L. Feeding ecology of the Brazilian silverside Atherinella brasiliensis (Atherinopsidae) in a sub-tropical estuarine ecosystem. J. Mar. Biol. Assoc. U.K., v. 91, n. 6, p. 1197-1205, 2010.

DAEE - DEPARTAMENTO DE ÁGUAS E ENERGIA ELÉTRICA. Banco de Dados Hidrológicos, Hidrologia. São Paulo, Brasil, 2015. Available: <http://www.hidrologia.daee.sp.gov. br/>. Accessed: 2016 April 21.

DEFEO, O.; MCLACHLAN, A.; SCHOEMAN, D. S.; SCHLACHER, T. A.; DUGAN, J.; JONES, A.; LASTRA, M.; SCAPINI, F. Threats to sandy beach ecosystems: A review. Estuar. Coast. Shelf Sci., v. 81, n. 1, p. 1-12, 2009.

ESPOSITO, V.; ANDALORO, F.; BIANCA, D.; NATALOTTO, A.; ROMEO, T.; SCOTTI, G.; CASTRIOTA, L. Diet and prey selectivity of the red mullet, Mullus barbatus (Pisces: Mullidae), from the southern Tyrrhenian Sea: the role of the surf zone as a feeding ground. Mar. Biol. Res., v. 10, n. 2, p. $167-$ 178, 2013. 
FAVARO, L. F.; LOPES, S. C. G.; SPACH, H. L. Reprodução do peixe-rei, Atherinella brasiliensis (Quoy \& Gaimard) (Atheriniformes, Atherinidae), em uma planície de maré adjacente à gamboa do Baguaçu, Baía de Paranaguá, Paraná, Brasil. Rev. Bras. Zool., v. 20, n. 3, p. 501-506, 2003.

FAVARO, L. F.; OLIVEIRA, E. C.; VERANI, N. F. Estrutura da população e aspectos reprodutivos do peixe-rei Atherinella brasiliensis (Quoy \& Gaimard) (Ather iniformes, Atherinopsidae) em áreas rasas do complexo estuarino de Paranaguá, Paraná, Brasil. Rev. Bras. Zool., v. 24, n. 4, p. 1150-1156, 2007.

FAVERO, J. M. D.; DIAS, J. F. Juvenile fish use of the shallow zone of beaches of the Cananéia-Iguape coastal system, southeastern Brazil. Braz. J. Oceanogr., v. 63, n. 2, p. 103-114, 2015.

FÉLIX, F. C.; SPACH, H. L.; MORO, P. S.; SCHWARZ JR., R.; SANTOS, C.; HACKRADT, C. W.; HOSTIM-SILVA, M. Utilization patterns of surf zone inhabiting fish from beaches in Southern Brazil. Panam. J. Aquat. Sci., v. 2, n. 1, p. 27-39, 2007.

FERRY, L. A.; CAILLIET, G. M. Sample size and data analysis: are we characterizing and comparing diet properly? Proceedings of the Symposium of Feeding Ecology and Nutrition in Fish. San Francisco: International Congress on Biology of Fishes, 1996. p. 71-80.

FIGUEIREDO, J. L.; MENEZES, N. A. Manual de Peixes Marinhos do Sudeste do Brasil. II. Teleostei (1). São Paulo: Museu de Zoologia da Universidade de São Paulo, 1978. p. 110 p.

GAELZER, L. R.; ZALMON, I. R. Diel variation of fish community in sandy beaches of Southeastern Brazil. Braz. J. Oceanogr., v. 56, n. 1, p. 23-39, 2008.

GARCIA JÚNIOR, J.; NÓBREGA, M. F.; OLIVEIRA, J. E. L. Coastal fishes of Rio Grande do Norte, northeastern Brazil, with new records. Check List, v. 11, n. 3, p. 1-24, 2015.

GASPAR, G. A.; ÁVILA, I. H. Diversidad íctica en playas de Isla Cubagua, Venezuela. Bol. Investig. Mar. Cost., v. 38, n. 1, p. 7-23, 2009.

GILBERT, C. R.; CALDWELL, D. K. The American Atherinid fishes of the genus Coleotropis. Los Angeles County Museum, Contrib. Sci., v. 125, p. 1-16, 1967.

GOMES, M. P.; CUNHA, M. S.; ZALMON, I. R. Spatial and temporal variations of diurnal ichthyofauna on surf-zone of São Francisco do Itabapoana beaches, Rio de Janeiro State, Brazil. Braz. Arch. Biol. Techn., v. 46, n. 4, p. 653-664, 2003.

GONÇALVES, S. C.; MARQUES, J. C. The effects of season and wrack subsidy on the community functioning of exposed sandy beaches. Estuar. Coast. Shelf Sci., v. 95, n. 1, p. 165-177, 2011.

GONDOLO, G. F.; MATTOX, G. M. T.; CUNNINGHAM, P. T. M. Ecological aspects of the surf-zone ichthyofauna of Itamambuca Beach, Ubatuba, SP. Biota Neotrop., v. 11, n. 2, p. 183192,2011

HARRIS, L.; NEL, R.; HOLNESS, S.; SINK, K.; SCHOEMAN, D. Setting conservation targets for sandy beach ecosystems. Estuar. Coast. Shelf Sci., v. 150, Pt. A, p. 45-57, 2014.

HORN, M. H.; GAWLICKA, A. K.; GERMAN, D. P.; LOGOTHETIS, E. A.; CAVANAGH, J. W.; BOYLE, K. S. Structure and function of the stomachless digestive system in three related species of New World silverside fishes (Atherinopsidae) representing herbivory, omnivory, and carnivory. Mar. Biol., v. 149, n. 5, p. 1237-1245, 2006.

LASIAK, T. A. Juveniles, food and the surf zone habitat: implications for teleost nursery areas. S. Afr. J. Zool., v. 21, n. 1, p. $51-56,1986$
LASIAK, T.; MCLACHLAN, A. Opportunistic utilization of mysid shoals by surf-zone teleosts. Mar. Ecol. Prog. Ser., v. 37, p. 1-7, 1987.

LAYMAN, C. A. Fish assemblage structure of the shallow ocean surf-zone on the eastern shore of Virginia Barrier Islands. Estuar. Coast. Shelf Sci., v. 51, n. 2, p. 201-213, 2000.

LOPES, P. R. D.; OLIVEIRA-SILVA, J. T. Registro de Atherinella blackburni (Schultz) (Actinopterygii, Teleostei, Atherinopsidae) na praia de Ponta da Ilha, Ilha de Itaparica, Bahia, Brasil. Rev. Bras. Zool., v. 18, n. 1, p. 117-122, 2001.

MATAMOROS, W. A.; SCHAEFER, J. F.; KREISER, B. R. Annotated checklist of the freshwater fishes of continental and insular Honduras. Zootaxa, v. 2307, p. 1-38, 2009.

MATTOX, G. M. T.; GONDOLO, G. F.; CUNNINGHAM, P. T. M. Atherinella blackburni (Schultz, 1949) at Itamambuca Beach, Ubatuba, SP: ecological characterization and distribuition on the Brazilian coast (Teleostei: Atheriniformes: Atherinopsidae). Braz. J. Biol., v. 68, n. 2, p. 307-313, 2008.

MAZZEI, E.; JOYEUX, J. C.; SIMON, T. Length-weight relationships for juvenile and small-sized adult fishes of the surf zone. J. Appl. Ichthyol., v. 27, n. 4, p. 1137-1138, 2011.

NEL, R.; CAMPBELL, E. E.; HARRIS, L.; HAUSER, L.; SCHOEMAN, D. S.; MCLACHLAN, A.; DU PREEZ, D. R.; BEZUIDENHOUT, K.; SCHLACHER, T. A. The status of sandy beach science: Past trends, progress, and possible futures. Estuar. Coast. Shelf Sci., v. 150, Pt. A, p. 1-10, 2014.

NEVES, L. M.; PEREIRA, H. H.; COSTA, M. R.; ARAÚJO, F. G. Uso do manguezal de Guaratiba, Baía de Sepetiba, Rio de Janeiro, pelo peixe-rei Atherinella brasiliensis (Quo \& Gaimard) (Atheriniformes, Atherinopsidae). Rev. Bras. Zool., v. 23, n. 2, p. 421-428, 2006.

NIANG, T. M. S.; PESSANHA, A. L. M.; ARAÚJO, F. G. Dieta de juvenis de Trachinotus carolinus (Actinopterygii, Carangidae) em praias arenosas na costa do Rio de Janeiro. Iheringia Sér. Zool., v. 100, n. 1, p. 35-42, 2010.

NONOMURA, T.; HAYAKAWA, Y.; SUDA, Y.; OHTOMI, J. Habitat zonation of the sand-burrowing mysids (Archaeomysis vulgaris, Archaeomysis japonica and Liella ohshimai), and diel and tidal distribution of dominant Archaeomysis vulgaris, in an intermediate sandy beach at Fukiagehama, Kagoshima Prefecture, south. Plank. Benth. Res., v. 2, n. 1, p. 38-48, 2007.

NUNES, L. H.; MODESTO, R. P. Comportamento pluviométrico nos municípios atendidos pelo "Plano preventivo de Defesa Civil- PPDC”. Rev. Inst. Geol., v. 13, n. 1, p. 47-57, 1992.

ODEBRECHT, C.; DU PREEZ, D. R.; ABREU, P. C.; CAMPBELL, E. E. Surf zone diatoms: A review of the drivers, patterns and role in sandy beaches food chains. Estuar. Coast. Shelf Sci., v. 150, Pt. A, p. 24-35, 2014.

OKSANEN, J.; BLANCHET, F. G.; FRIEDLY, M.; KINDT, R.; LEGENDRE, P.; MCGLINN, D.; MINCHIN, P. R.; O'HARA, R. B.; SIMPSON, G. L.; SOLYMOS, P.; STEVENS, M. H. H.; SZOECS, E.; WAGBER, H. Vegan: Community Ecology Package. R package version 2.4-0, 2016. Available in: $<$ https:// CRAN.R-project.org/package=vegan $>$. Accessed: 2017 May 29.

OLIVEIRA, R. E. M. C. C.; PESSANHA, A. L. M. Fish assemblages along a morphodynamic continuum on three tropical beaches. Neotrop. Ichthyol., v. 12, n. 1, p. 165-175, 2014. 
PALMEIRA, L. P.; MONTEIRO-NETO, C. Ecomorphology and food habits of teleost fises Trachinotus carolinus (Teleostei: Carangidae) and Menticirrhus littoralis (Teleostei: Sciaenidae), inhabiting the surf zone off Niterói, Rio de Janeiro, Brazil. Braz. J. Oceanogr., v. 58, n.spe. 4, p. 1-9, 2010.

PATTRICK, P.; STRYDOM, N. A. The effects of exposure in sandy beach surf zones on larval fishes. J. Fish Biol., v. 84, n. 5, p. 1354-1376, 2014.

PEREIRA, P. H. C.; BARROS, B.; ZEMOI, R.; FERREIRA, B. P. Ontogenetic diet changes and food partitioning of Haemulon spp. coral reef fishes, with a review of the genus diet. Rev. Fish Biol. Fish., v. 25, n. 1, p. 245-260, 2014.

PESSANHA, A. L. M.; ARAÚJO, F. G. Recrutamento do peixerei, Atherinella brasiliensis (Quoy \& Gaimard) (Atheriniformes, Atherinopsidae), na margem continental da Baía de Sepetiba, Rio de Janeiro, Brasil. Rev. Bras. Zool., v. 18, n. 4, p. 1265-1274, 2001.

PIEDRAS, F. R.; ODEBRECHT, C. The response of surf-zone phytoplankton to nutrient enrichment (Cassino Beach, Brazil). J. Exp. Mar. Biol. Ecol., v. 432-433, p. 156-161, 2012.

PIEDRAS, S. R. N.; POUEY, J. L. O. F. Alimentação do peixe-rei (Odontesthes bonariensis, Atherinopsidae) nas lagoas Mirim e Mangueira, Rio Grande do Sul, Brasil. Iheringia Sér. Zool., v. 95 , n. 2 , p. $117-120,2005$.
R CORE TEAM. R: A language and environment for statistical computing. R Foundation for Statistical Computing, Vienna, Austria, 2015. Available: <http://www.R-project.org/>. Accessed: 2017 May 29.

REEBS, S. G. Plasticity of diel and circadian activity rhythms in fishes. Rev. Fish Biol. Fish., v. 12, n. 4, p. 349-371, 2002.

RODRIGUES, F. L.; BEMVENUTI, M. D. A. Hábito alimentar e osteologia da boca do peixe-rei, Odontesthes humensis de Buen (Atheriniformes, Atherinopsidae) na Lagoa Mirim, Rio Grande do Sul, Brasil. Rev. Bras. Zool., v. 18, n. 3, p. $793-$ $802,2001$.

SANTANA, F. M. S.; SEVERI, W.; FEITOSA, C. V.; ARAÚJO, M. E. The influence of seasonality on fish life stages and residence in surf zones: a case of study in a tropical region. Biota Neotrop., v. 13, n. 3, p. 181-192, 2013.

SCHOENER, T. W. The controvesy over interspecific competition. Am. Sci., v. 70, n. 6, p. 586-595, 1982.

SCHULTZ, L. P. A further contribution to the ichthyology of Venezuela. Proc. United States Natl. Museum, v. 99, n. 3235, p. $1-211,1949$.

TIRASIN, E. M.; JØRGENSEN, T. An evaluation of the precision of diet description. Mar. Ecol. Prog Ser., v. 182, p. 243$252,1999$.

WARD-CAMPBELL, B. M. S.; BEAMISH, F. W. H.; KONGCHAIYA, C. Morphological characteristics in relation to diet in five coexisting Thai fish species. J. Fish Biol., v. 67, n. 5, p. $1266-1279,2005$. 